\title{
Seasonal variation of the water quality of rivers and streams of eastern Mediterranean
}

\author{
M. Lazaridou-Dimitriadou
}

Lazaridou-Dimitriadou, M. 2002. Seasonal variation of the water quality of rivers and streams of eastern Mediterranean. - Web Ecol. 3: 20-32.

\begin{abstract}
Biotic and abiotic data on undisturbed or moderately disturbed lotic sites from a number of studies carried out in northern Greece showed that large rivers differ from small rivers, streams or creeks in terms of diversity, dominant groups and the kind of taxa (concerning the sensitivity of the taxa according to Biological Monitoring Working Party (BMWP) biotic scores). This is mainly due to the differences in their physical characteristics. Correlation of the environmental variables using MDA (multiple discriminant analysis) showed that the chief differentiating factors among the above water bodies are substrate, total suspended solids (TSS), conductivity, slope and temperature. Additionally, there is no clear phenological seasonality in the majority of the dominant benthic macroinvertebrate groups when undisturbed or moderately disturbed sites of mountainous creeks and small rivers are examined. By contrast, in downstream sites of long rivers, seasonality characterizes the dominant benthic macroinvertebrate groups, as it does for other Mediterranean animals.
\end{abstract}

M. Lazaridou-Dimitriadou (mlazarid@bio.auth.gr), Dept of Zoology, School of Biology, Fac. of Science, Aristotle Univ., GR-54006, Thessaloniki, Greece.

The use of biological methods for monitoring (biomonitoring) the ecological quality of running waters is already a widespread approach in Europe. It provides information on water quality and ecology both before and during sampling, in contrast to chemical approaches which only characterize the water system during sampling (Metcalfe 1989). However, a combination of both approaches, physicochemical and biotic, has been shown to be the most appropriate method for pollution monitoring (Hellawell 1986, Metcalfe 1989, Mason 1991).

Biomonitoring includes both sublethal changes at the cellular or tissue level (Vukmirovic et al. 1994, Cajaraville et al. 1995) and changes in community (Metcalfe 1989, Graca et al. 1989, Castella et al. 1995). The use of changes in community structure for monitoring freshwater pollu- tion, commonly involves benthic macroinvertebrates, because this group is considered as the most appropriate biological indicator of water quality in EU countries (Metcalfe 1989) including Greece (Anagnostopoulou 1992, Anagnostopoulou et al. 1994). Benthic macroinvertebrates are the most appropriate biotic indicators for the following reasons: 1) These organisms are relatively sedentary and are therefore representative of local conditions. 2) Macroinvertebrate communities are very heterogeneous, consisting of representatives of several phyla. The probability that at least some of these organisms will react to a particular change of environmental conditions, is therefore high (De Pauw and Vanhooren 1983, Hellawell 1986, Metcalfe 1989, Mason 1991). Other groups of organisms (fish, phytoplakton, etc) possess some, but not all, of these im- 
portant attributes. 3) Macroinvertebrates are differentially sensitive to pollutants of various types, and react to them quickly; also, their communities are capable of a gradient response to a broad spectrum of kinds and degrees of stress. 4) Their life spans are long enough to provide a record of environmental quality. 5) Macroinvertebrates are ubiquitous, abundant and relatively easy to collect. Furthermore, their indentificaton and enumeration is not as tedious and difficult as that of microorganisms and plankton.

Greece is one of the EU countries that have no specialized institution to undertake the regular monitoring of running waters. During the last seven years, two large rivers (Aliakmon and Axios) and five small ones (Aggitis, Maurolakkas, Basdekis, Kokkinolakas, and Asprolakas) have been studied in the N. Greece in order to assess an appropriate method for biomonitoring the ecological quality of Hellenic freshwater ecosystems as this is determined by the EU Proposal Directive [Commission of the European Communities COM (1998) 76 final] (Anagnostopoulou 1992, Anagnostopoulou et al. 1994, Copeland et al. 1997, Ford et al. 1998, Langrick et al. 1998, Artemiadou et al. 1999, Drouin et al. 1999, Jennings et al. 1999, Yfantis et al. 1999). The above studies involve the comparative application of several European biotic indices, scores and multivariate statistical methods, to establish a Hellenic biotic index, which would be applied to the special hydrological and climatological conditions in Greece (high temperatures during summer, strikingly variable discharge throughout the year) because the applied European biotic indices and scores do not totally match (Lazaridou-Dimitriadou et al. 2000).

In the present study, various undisturbed sites from the above studies were examined at monthly (Axios and Aliakmon rivers) or seasonal basis (Olympias and Skouries streams) in order to find out the factors affecting macrobenthic community structure in rivers and streams and to investigate seasonal patterns of macroinvertebrate abundance and diversity. For the above comparisons the seasonal physicochemical and benthic macroinvertebrate community structure and abundance were analysed from undisturbed or moderately disturbed sites, one at the upper reaches and the other at the downstream stretch, in two rivers (Aliakmon and Axios) and two streams (Piavitsa-Asprolakkas, Kipouristras) of N. Greece.

\section{Materials and methods}

\section{Study area}

Available data were limited in this region as is mentioned above. Data available from past studies were used in this review (Ford et al. 1998, Langrick et al. 1998, Bobori and Mourelatos 1999, Drouin et al. 1999, Jenning et al. 1999, Yfantis et al. 1999, Lazaridou-Dimtiriadou et al. 2000).

\section{Skouries and Olympias streams}

Skouries and Olympias areas are located on the east coast of Chalkidiki in northern Greece. All streams originate from the Stratonikon mountain range and flow through a mountainous landscape, except for some flat areas close to Olympias town.

Concerning the Olympias area, Kipouristras Creek (which has two sampling stations) flows from south to north in a semi-mountainous area before its confluence with Mavrolakkas River (three sampling stations). The latter follows a west-to-east course and then discharges into the gulf of Strimonikos, ca $1 \mathrm{~km}$ north of Olympias town. Within the area of Olympias, agricultural activities are relatively developed and concentrated around the flat regions close to Olympias town (Table 1). These areas also support a number of livestock farms with semi-wild pigs and goats. The main human activities in the area are related to ore mining. These include both old and currently active mine shafts, a mill plant for mineral enrichment and a backfilling plant, which are currently not fully operating, ore (mainly arsenopyrite) stockpiles, waste rock deposits (Platia Fire), an old tailings pond and four settling ponds for the precipitation of metals contained in ground water flowing from the old adits.

The Skouries area, is a mountainous region, is largely covered by forest. Its north side is adjacent to an area protected by "Natura 2000" EU Directive, located in between

Table 1. Physical characteristics and sources of pollution of the sampling stations of Kipouristras stream at Olympias area (OL1and OL4) and Piavitsa (SK1) - Asprolakka (SK4) streams at Skouries area.

\begin{tabular}{lcccccc}
\hline Station & Longitude & Latitude & $\begin{array}{l}\text { Distance from } \\
\text { source }(\mathrm{km})\end{array}$ & $\begin{array}{l}\text { Altitude } \\
(\mathrm{m})\end{array}$ & $\begin{array}{l}\text { Slope } \\
\left(\mathrm{m} \mathrm{km}^{-1}\right)\end{array}$ & Sources \\
\hline OL1 & $23^{\circ} 42^{\prime}$ & $40^{\circ} 34^{\prime}$ & 3.06 & 299.92 & 129.12 & $\begin{array}{l}\text { Livestock farm } \\
\text { OL4 }\end{array} 2^{\circ} 44^{\prime}$ \\
$23^{\circ} 43^{\prime}$ & $40^{\circ} 36^{\prime}$ & 7.36 & 39.99 & 130.32 & $\begin{array}{l}\text { Tailing ponds } \\
\text { SK1 }\end{array}$ \\
\hline SK4 & $23^{\circ} 46^{\circ}$ & $40^{\circ} 21^{\prime}$ & 0.10 & 500.03 & 76.91 & Mn-rich deposits \\
\hline
\end{tabular}


Olympias and Skouries. At present the main human activities within this study area concern woodcutting, and stock-raising (Table 1). Asprolakkas stream is the main stream that runs through Skouries area and derives from the confluence of Kerasia and Piavitsa creeks.

\section{Aliakmon river}

The springs of the river Aliakmon is located in Grammos and Vernon Mountains, in northwestern Greece. It discharges into the gulf of Thermaikos. Upstream sites, located along the main course of the river before the artificial lake of Polyphyto, do not receive significant amounts of pollutants apart from Kostarazi (sewage wastes) and Greveniotis (sewage and industrial wastes). Downstream sites, located in tributaries of the Aliakmon (the rivers Moglenitsas, Edesseos and the drainage channel, Canal 66) are subject to agricultural (pesticides and fertilizers), urban (sewage and detergents) and industrial (mainly fruit and vegetable canneries) sources of pollution (Anagnostopoulou 1992, Kouimtzis et al. 1994). The physical characteristics of the studied sites of this river are shown in Table 2.

\section{Axios river}

The river Axios originates in the Sar mountains of the Former Yugoslav Republic of Macedonia (FYROM) and discharges into the Thermaikos Gulf to the south-west of the city of Thessaloniki in northern Greece. Of its total length of $320 \mathrm{~km}$ only the last $80 \mathrm{~km}$ is within Greek territory and the study area is thus confined to the lower reaches of the river. Catchment land-use is predominantly agricultural and diffuse pollution as a result of soil erosion and pesticide and fertiliser run-off may be expected. Local settlements and industries are small, but pollution loads may also arise due to point source domestic wastewaters (including sewage and detergents), industrial effluents (including textile, slaughterhouse and dairy wastes), and polluted tributaries (carrying agricultural drainage waters).
The physical characteristics of the studied sites of this river are shown in Table 2.

\section{Sampling of macroinvertebrates and physicochemical parameters}

One sample of benthic macroinvertebrates was taken into consideration from one site at the upper reaches and one site at the downstream stretch of each of the rivers or streams mentioned above. This is clearly shown by the difference in the substrate composition between the two sites at least in the long rivers Aliakmon and Axios (Table 3). Details of the sampling procedure, the treatment of samples, and the measurement of the different physicochemical parameters are given in a previous paper (LazaridouDimitriadou et al. 2000).

\section{Statistical analyses}

In order to compare the biotic parameters in the above mentioned lotic systems (rivers and streams), seasonal data (physicochemical data) from an upstream site and a downstream stretch were examined and analysed as well (Tables 5-9). Several criteria had to be met for inclusion of these undisturbed or moderately disturbed sites into the dataset (Jennings et al. 1999): 1) Taxonomic resolution had to be comparable throughout the dataset. This forced the recombining of several species to genus or family level. 2) Each site had to be sampled in at least two seasons (spring and autumn) to lessen the chance of seasonal taxa being missed. 3) Sites had to be relatively unstressed.

Adhering to these criteria we produced a dataset of 24 sites $(5$ from creeks or streams in Olympias area, 8 from creeks or streams in Skouries area, 9 in the Aliakmon and two in the Moglenitsas river which merges with Aliakmon) from a total of 268 studied sites. Only spring and autumn data were used. A list of 131 taxa was compiled, identified mostly to genus level. Exceptions were Oligochaetes (to

Table 2. Physical characteristics and sources of pollution of the sampling stations of Aliakmon (Grevena and Niseli) and Axios rivers (Euzoni and Anatoliko).

\begin{tabular}{|c|c|c|c|c|c|}
\hline Site & $\begin{array}{l}\text { Distance from } \\
\text { source }(\mathrm{km})\end{array}$ & Altitude (m) & Longitude & Latitude & Land use \\
\hline \multicolumn{6}{|l|}{ Aliakmon river } \\
\hline 1 Grevena $(\mathrm{G})$ & 116.5 & 520 & $21^{\circ} 32^{\prime}$ & $40^{\circ} 13^{\prime}$ & $\begin{array}{l}\text { Agricultural runoff and } \\
\text { urban wastes }\end{array}$ \\
\hline 2 Niseli (N) & 290 & 10 & $22^{\circ} 28^{\prime}$ & $40^{\circ} 35^{\prime}$ & $\begin{array}{l}\text { Agricultural runoff and } \\
\text { urban wastes }\end{array}$ \\
\hline \multicolumn{6}{|l|}{ Axios river } \\
\hline 1 Evzoni (E) & $1^{*}$ & 40 & $22^{\circ} 32^{\prime}$ & $41^{\circ} 05^{\prime}$ & Agricultural \\
\hline 2 Anatoliko (A) & $64^{*}$ & 5 & $22^{\circ} 42^{\prime}$ & $40^{\circ} 39^{\prime}$ & Agricultural \\
\hline
\end{tabular}

*This distance is calculated from the borders with FYROM. 
Table 3. Substrate categories (1: >70\% bolders, cobbles pebbles, 2: >70\% gravel, sand and silt, 3: equally represented) of Evzoni and Anatoliko at Axios river, Grevena and Niseli at Aliakmon river, two sites from Olympias area (OL1 and OL4) and Piavitsa (SK1) Asprolakka (SK4) streams at Skouries area.

\begin{tabular}{lcccccccc}
\hline & & \multicolumn{3}{c}{ River stations } & & & \\
Date & SK1 & SK4 & OL1 & OL4 & Evzoni & Anatoliko & Grevena & Niseli \\
\hline November & 3 & 3 & 2 & 2 & 3 & 2 & 3 & 2 \\
January & 3 & 1 & 3 & 3 & 3 & 2 & 3 & 2 \\
March & 3 & 1 & 1 & 3 & 3 & 2 & 3 & 2 \\
June & 3 & 1 & 3 & 3 & 1 & 2 & 3 & 2 \\
August & 3 & 3 & 3 & 2 & 1 & 2 & 3 & 2 \\
\hline
\end{tabular}

class) and Diptera (to family). Sites and species classified by the clustering FUZZY technique (Equihua 1990), based on fuzzy sets, were used in Multiple Discriminant Analysis (MDA) relating the FUZZY site groupings to their environmental variables. MDA was implemented through the discriminant function of the computer program SPSS (Klecka 1975).

\section{Seasonality}

In order to examine whether seasonality affects the phenology of benthic macroinvertebrate community structure the abundance of each benthic taxon (sampled with the three min kick/sweep method) was monthly or seasonally followed at two representative sites, one at the upper reaches and the other in the downstream stretch in each of the mentioned above rivers or streams.

\section{Results}

\section{Correlation of site groupings with environmental parameters}

MDA was used to attempt to predict the FUZZY groups of sites using environmental data only. The examination of the standardised canonical discriminant functions gave an indication of the importance of the various environmental parameters contributions to the prediction (Table 4).

In the first discriminant function the five most important variables (substrate, total suspended solids (TSS), conductivity, slope and temperature) seemed to be related to the longitudinal positioning of a site on a water course.

\section{Seasonality}

In all the Greek rivers and creeks, mainly because of reduced river vegetation, total suspended solids (which according to MDA is one of the most important discriminating environmental variables) increase (Bobori and
Mourelatos 1999) after a rainy season or after snow melting or both (Tables 5 and 6). This causes differences in the makeup of biocommunities (Tables 5 and 6). High discharge (in January) are favoured by the sensitive macroinvertebtate groups whereas tolerant macroinvertebrate groups appear in the beginning of spring (Table 10A, B). Nutrients exceed the EU limits in the two studied rivers only during summer (Tables 8 and 9).

In Aliakmon river Plecoptera mainly appear in January, Trichoptera mainly in July-August and then in October. Ephemeroptera, although some genera mainly appear from October to February and others in June (Table 10A), as well as Oligochaeta and Chironomidae, appear all the year round (Fig. 1a, Table 10A). In Axios river there are almost no Plecoptera since Axios represents the last $70 \mathrm{~km}$ of its length in the Greek territory. As to the other groups some Trichoptera appear mainly in June, Ephmeroptera appear from June to November, Oligochaeta from January to May, Chironomidae from June to February showing one peak in summer and one in winter (Fig. 1b, Table 10B). On the other hand, in Olympiada and Skouries creeks, all the above groups appear throughout the year, except for Ephemeroptera that peak in June and Oligochaeta that peak in August-November (Table 10C, D).

Comparing the sum of the number of families seasonally, over the months January, March, June, August and November, it is clear that it declines ca $70 \%$ from the small

Table 4. Standardized canonical discriminant function coefficients of environmental variables. Only the 10 most influencing parameters are shown and ranked.

\begin{tabular}{lr}
\hline Parameters & Coefficients \\
\hline Minimum dominant particle size & -11.06262 \\
Total suspended solids $\left(\mathrm{mg} \mathrm{l}^{-1}\right)$ & 11.04113 \\
Conductivity $(\mu \mathrm{S})$ & 9.61441 \\
Slope of site $\left(\mathrm{m} \mathrm{km}^{-1}\right)$ & 9.59768 \\
Mean water temperature $\left({ }^{\circ} \mathrm{C}\right)$ & -7.02949 \\
Mean substrate type & 6.01889 \\
Altitude of site $(\mathrm{m})$ & -5.98196 \\
Mean substrate heterogeneity & 4.82803 \\
Total oxidized nitrogen $\left(\mathrm{mg} \mathrm{l}^{-1}\right)$ & 3.68229 \\
Maximum water velocity $\left(\mathrm{m} \mathrm{s}^{-1}\right)$ & -3.38036 \\
\hline
\end{tabular}


Table 5. Physicochemical parameters of sampling stations (Grevena $(\mathrm{G})$ and Niseli $(\mathrm{N})$ ) in Aliakmon river.

\begin{tabular}{|c|c|c|c|c|c|c|c|}
\hline Date & Aliakmon river & $\begin{array}{l}\text { Oxygen } \\
\left(\mathrm{mg} \mathrm{l}^{-1}\right)\end{array}$ & $\mathrm{pH}$ & $\begin{array}{l}\text { Temp. } \\
\left({ }^{\circ} \mathrm{C}\right)\end{array}$ & $\begin{array}{l}\text { Conductivity } \\
(\mu S)\end{array}$ & $\begin{array}{l}\text { TSS } \\
\left(\mathrm{mg} \mathrm{l}^{-1}\right)\end{array}$ & $\begin{array}{l}\text { Discharge } \\
\left(\mathrm{m}^{3} \mathrm{~s}^{-1}\right)\end{array}$ \\
\hline November & $\begin{array}{l}\text { Max. } \\
\text { Min. }\end{array}$ & $\begin{array}{l}14.1(\mathrm{G}) \\
10.0(\mathrm{~N})\end{array}$ & $\begin{array}{l}8.19(\mathrm{G}) \\
7.86(\mathrm{~N})\end{array}$ & $\begin{array}{r}11.2(\mathrm{~N}) \\
4.7(\mathrm{G})\end{array}$ & $\begin{array}{l}399(\mathrm{G}) \\
399(\mathrm{~N})\end{array}$ & $\begin{array}{r}32.8(\mathrm{~N}) \\
0.2(\mathrm{G})\end{array}$ & $\begin{array}{r}37.1(\mathrm{~N}) \\
3.2(\mathrm{G})\end{array}$ \\
\hline \multicolumn{8}{|l|}{ Site exceeding the EU values } \\
\hline January & $\begin{array}{l}\text { Max. } \\
\text { Min. }\end{array}$ & $\begin{array}{l}11.0(\mathrm{G}) \\
10.2(\mathrm{~N})\end{array}$ & $\begin{array}{l}8.22(\mathrm{G}) \\
7.87(\mathrm{~N})\end{array}$ & $\begin{array}{l}7.8(\mathrm{~N}) \\
6.5(\mathrm{G})\end{array}$ & $\begin{array}{l}426(\mathrm{G}) \\
368(\mathrm{~N})\end{array}$ & $\begin{array}{l}148.7(\mathrm{~N}) \\
103.7(\mathrm{G})\end{array}$ & $\begin{array}{l}31.8(\mathrm{~N}) \\
\mathrm{NM}(\mathrm{G})\end{array}$ \\
\hline Site exceeding the EU values & & & & & Grevena & & \\
\hline March & Max. & $11.8(\mathrm{G})$ & $8.48(\mathrm{G})$ & $12.1(\mathrm{~N})$ & $501(\mathrm{~N})$ & $7.5(\mathrm{~N})$ & $3.5(\mathrm{G})$ \\
\hline Site exceeding the EU values & Min. & $8.9(\mathrm{~N})$ & $8.12(\mathrm{~N})$ & $7.3(\mathrm{G})$ & $\begin{array}{l}470(\mathrm{G}) \\
\text { Grevena } \\
\text { and Niseli }\end{array}$ & $2.7(\mathrm{G})$ & $3.5(\mathrm{~N})$ \\
\hline June & Max. & $9.2(\mathrm{G})$ & $8.50(\mathrm{G})$ & $22.9(\mathrm{G})$ & $503(\mathrm{~N})$ & $34.2(\mathrm{G})$ & $112.3(\mathrm{~N})$ \\
\hline Site exceeding the EU values & Min. & $8.1(\mathrm{~N})$ & $7.92(\mathrm{~N})$ & $20.3(\mathrm{~N})$ & $\begin{array}{l}377 \text { (G) } \\
\text { Niseli }\end{array}$ & $8.9(\mathrm{~N})$ & $110.5(\mathrm{G})$ \\
\hline August & $\begin{array}{l}\text { Max. } \\
\text { Min. }\end{array}$ & $\begin{array}{r}7.7(\mathrm{G}) \\
\mathrm{NM}(\mathrm{N})\end{array}$ & $\begin{array}{l}8.30(\mathrm{G}) \\
7.50(\mathrm{~N})\end{array}$ & $\begin{array}{l}21.5(\mathrm{~N}) \\
20.9(\mathrm{G})\end{array}$ & $\begin{array}{l}516(\mathrm{~N}) \\
436(\mathrm{G})\end{array}$ & $\begin{array}{l}39.3(\mathrm{G}) \\
10.9(\mathrm{~N})\end{array}$ & $\begin{array}{r}113.9(\mathrm{~N}) \\
1.0(\mathrm{G})\end{array}$ \\
\hline Site exceeding the EU values & & & & & $\begin{array}{l}\text { Grevena }(\mathrm{G}) \\
\text { and Niseli }(\mathrm{N})\end{array}$ & & \\
\hline
\end{tabular}

(Olympias and Skouries areas) to the large rivers (Aliakmon) and up to $85 \%$ from the small to the plain parts of long rivers (Axios river) (Table 10). Additionally, comparing the scores of sensitive or moderately sensitive taxa, with
BMWP scores (Chesters 1980) of 10 down to 5 , seasonally it is noticed that $80 \%$ more sensitive taxa are found in small (as Skouries and Olympias) and large rivers (as Aliakmon) than in the plain parts of long rivers (e.g. Axios river).

Table 6. Physicochemical parameters of sampling stations (Euzoni (E) and Anatoliko (A)) in Axios river.

\begin{tabular}{|c|c|c|c|c|c|c|c|}
\hline Date & Axios river & $\begin{array}{l}\text { Oxygen } \\
\left(\mathrm{mg} \mathrm{l}^{-1}\right)\end{array}$ & $\mathrm{pH}$ & $\begin{array}{l}\text { Temp. } \\
\left({ }^{\circ} \mathrm{C}\right)\end{array}$ & $\begin{array}{l}\text { Conductivity } \\
(\mu S)\end{array}$ & $\begin{array}{l}\text { TSS } \\
\left(\mathrm{mg} \mathrm{l}^{-1}\right)\end{array}$ & $\begin{array}{l}\text { Discharge } \\
\left(\mathrm{m}^{3} \mathrm{~s}^{-1}\right)\end{array}$ \\
\hline November & $\begin{array}{l}\text { Max. } \\
\text { Min. }\end{array}$ & $\begin{array}{r}12(\mathrm{~A}) \\
11.4(\mathrm{E})\end{array}$ & $\begin{array}{l}8.22(\mathrm{~A}) \\
8.07(\mathrm{E})\end{array}$ & $\begin{array}{l}7.9(\mathrm{~A}) \\
7.3(\mathrm{E})\end{array}$ & $\begin{array}{l}429(\mathrm{E}) \\
426(\mathrm{~A})\end{array}$ & $\begin{array}{l}56.8(\mathrm{~A}) \\
16.3(\mathrm{E})\end{array}$ & $\begin{array}{r}105.8(\mathrm{E}) \\
89.3(\mathrm{~A})\end{array}$ \\
\hline \multicolumn{8}{|l|}{ Site exceeding the EU limits } \\
\hline \multirow{2}{*}{$\begin{array}{l}\text { January } \\
\text { Site exceeding the EU limits }\end{array}$} & Max. & $15.2(\mathrm{E})$ & $7.50(\mathrm{~A})$ & $6.8(\mathrm{~A})$ & $421(\mathrm{E})$ & 66.0 (A) & 125.9 (A) \\
\hline & Min. & $11.4(\mathrm{~A})$ & $7.45(\mathrm{E})$ & $5.2(\mathrm{E})$ & $\begin{array}{l}408(\mathrm{~A}) \\
\text { Evzoni (E) and } \\
\text { Anatoliko (A) }\end{array}$ & $32.8(\mathrm{E})$ & $59.7(\mathrm{E})$ \\
\hline March & Max. & $9.6(\mathrm{E})$ & $8.22(\mathrm{~A})$ & $10.8(\mathrm{~A})$ & 385 (A) & $73.3(\mathrm{E})$ & $58.8(\mathrm{~A})$ \\
\hline \multicolumn{8}{|l|}{ Site exceeding the EU limits } \\
\hline June & Max. & $15.1(\mathrm{~A})$ & $9.47(\mathrm{~A})$ & $30.2(\mathrm{~A})$ & $1100(\mathrm{~A})$ & $174.4(\mathrm{~A})$ & $61.5(\mathrm{E})$ \\
\hline Site exceeding the EU limits & Min. & $9.4(\mathrm{E})$ & $8.31(\mathrm{E})$ & $\begin{array}{l}23.2(\mathrm{E}) \\
\text { Anatoliko }\end{array}$ & $\begin{array}{l}501(\mathrm{E}) \\
\text { Evzoni and } \\
\text { Anatoliko }\end{array}$ & $20.8(\mathrm{E})$ & - \\
\hline August & Max. & $10.4(\mathrm{~A})$ & $9.00(\mathrm{~A})$ & $25.3(\mathrm{~A})$ & $537(\mathrm{~A})$ & $48.6(\mathrm{E})$ & $7.2(\mathrm{E})$ \\
\hline & Min. & $8.6(\mathrm{E})$ & $8.16(\mathrm{E})$ & $21.6(\mathrm{E})$ & $472(\mathrm{E})$ & $46.0(\mathrm{~A})$ & 35.7 (A) \\
\hline Site exceeding the EU limits & & & Anatoliko & Anatoliko & $\begin{array}{l}\text { Evzoni and } \\
\text { Anatoliko }\end{array}$ & & \\
\hline
\end{tabular}


Table 7. Physicochemical parameters of sampling stations at Olympias (OL) and Skouries (SK) areas.

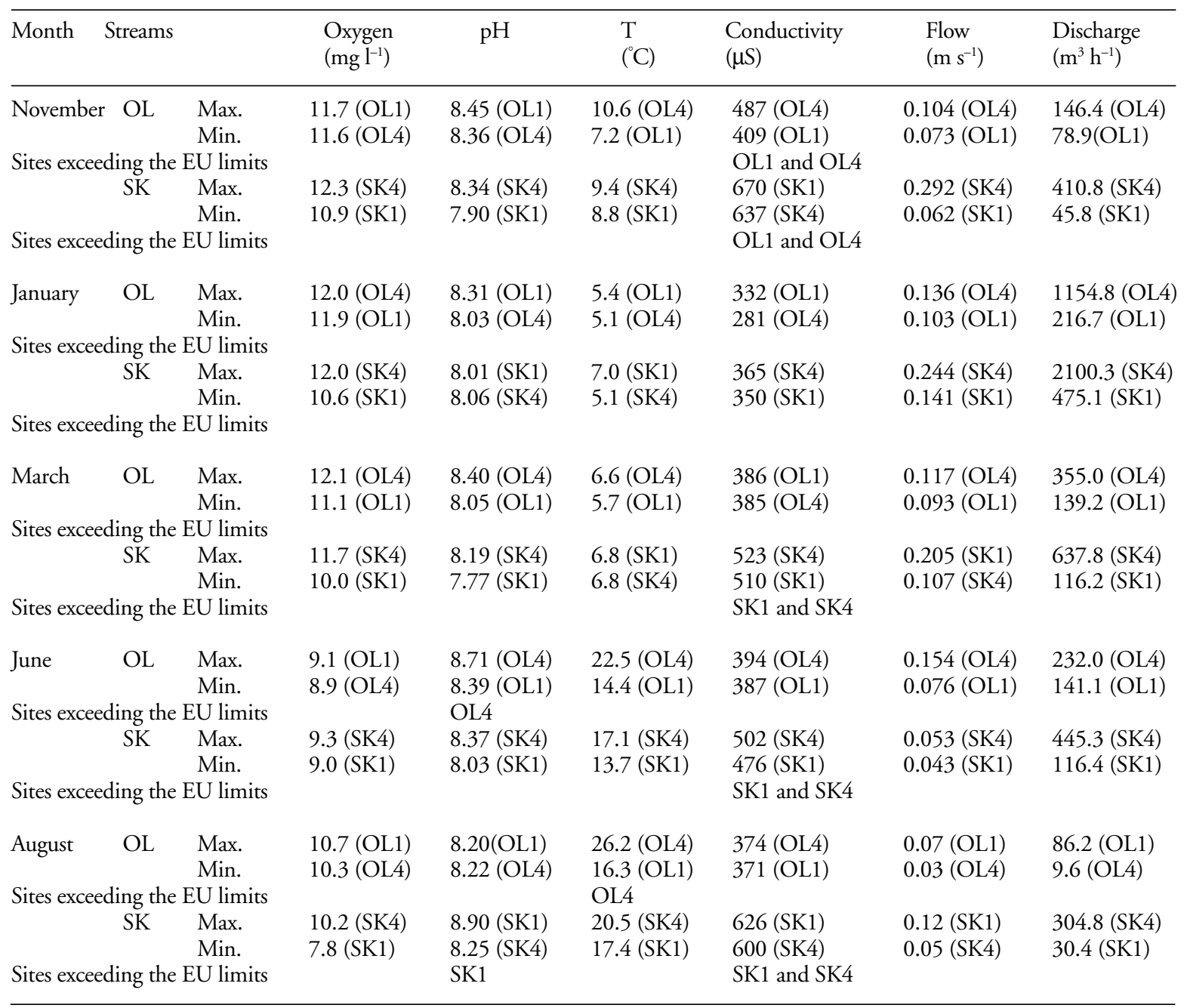

* OL1 + OL2 from Kipouristra creek.

* SK1 = Piavitsa and SK2 = Asprolakka creek.

\section{Discussion}

Concerning the studied sites, the results suggest that the substrate and TSS were found to be the most important in the studied sites in determining community structure. Conductivity, slope and temperature were also found to be highly influential factors. The influence of substrate on macroinvertebrate communities, found as a differentiating factor by MDA, has long been known as such (Hynes 1970). In Greek rivers, discharge is much higher during winter and the beginning of spring whereas conductivity declines. The latter increases in summer, mainly in June, causing a deterioration of biocommunities in summer (June-August). The results of this study vary from others in the strength of chemical parameters as influencing fac- tors on community structure. Wright (1995) found alkalinity to be the most important factor by MDA, whilst Marchant et al. (1994) found a strong $\mathrm{pH}$ and conductivity gradient. Such strong gradients are not apparent in this study apart from conductivity. This is likely to be because such parameters are of more use in detecting differences between, rather than along rivers. Wright's (1995) and Marchant's et al. (1994) studies investigated 41 and 9 rivers respectively, whilst this study investigates only 4 systems (Olympias, Skouries, Aliakmon and Moglenitsas). Therefore factors relating to differences between rivers were of less importance in this study.

Concerning the distribution of various taxa along the environmental gradients it is clear that Trichoptera largely show a preference for more diverse, coarser substrates, 
Table 8. Nutrients at Axios and Aliakmon river (ND: not detectable).

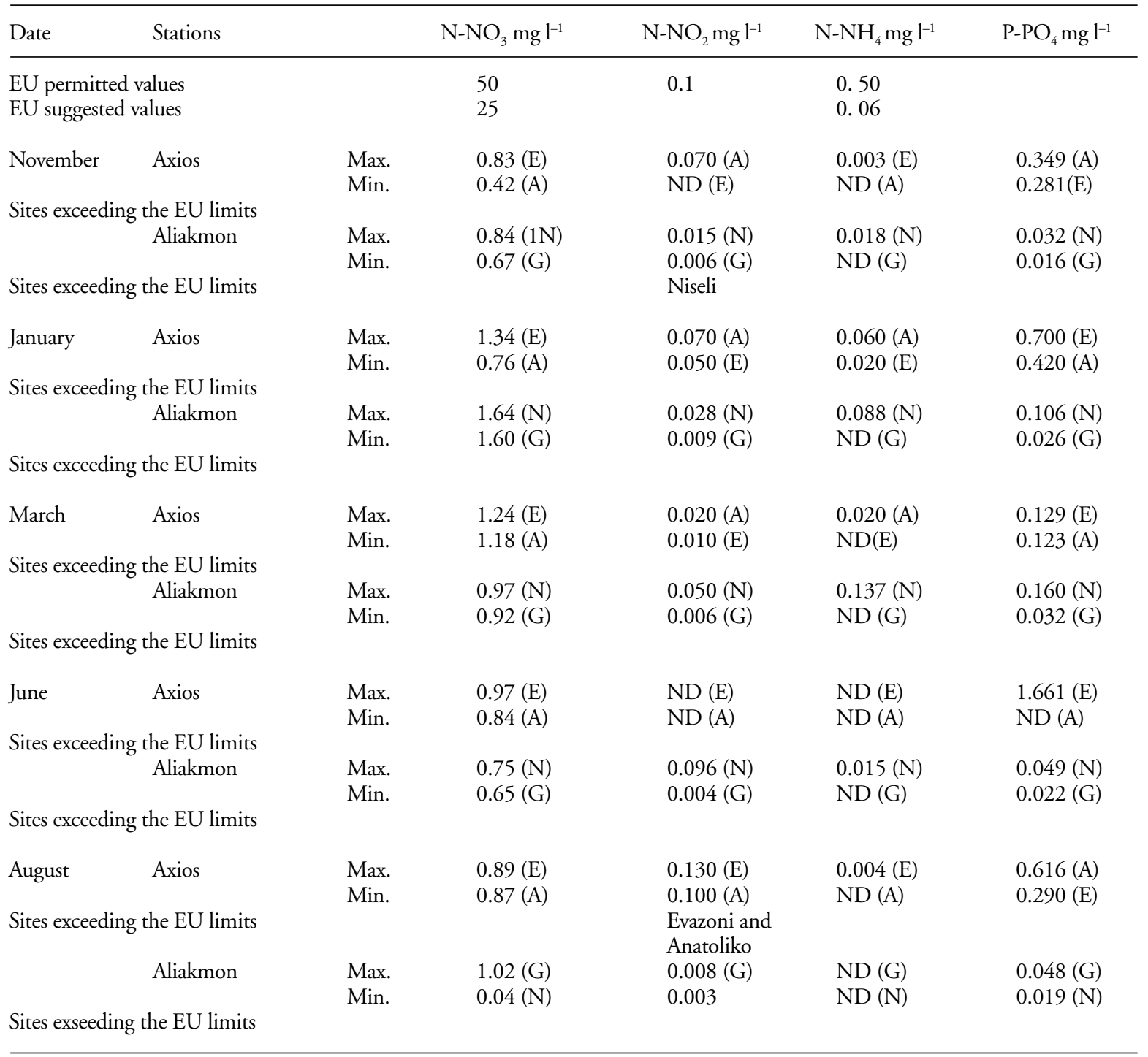

rather than depositional ones. The Ephemeroptera show a more general distribution, with different taxa showing preferences for both streams and larger river sites. The Potamanthidae were found only in the larger Aliakmon sites, where they live on the sand and gravel. The prosobranch families (especially the Hydrobiidae) were largely confined to turbulent stream sites due to their higher dissolved oxygen requirements (e.g. Skouries and Olympias). Conversely, the pulmonates (Physidae) were found to flourish mainly in the Aliakmon and less in the Axios sites, due to their ability to exploit less turbulent microhabitats.

Concerning seasonality, the study of the two representative sites in each Greek lotic system showed that streams and creeks must be regarded separately from large and long rivers according to the MDA analysis, because these systems differ mainly in their physical characteristics and less on the strength of their chemical characteristics. This can perhaps be explained by the fact that the studied small rivers, here in Greece, run mainly in woody areas and their physical characteristics do not change much along them, so biocommunities do not have to accomodate to striking differences. Whereas in the plain parts of long rivers, as is the case for Axios river, different land uses along them cause differences in the physicochemical parameters. So, the different benthic macroinvertebrate groups flourish at different times of the year, taking advantage of the most favourable conditions for them to fulfill their cycles. Consequently, the evolution of the biocommunity structure in 
Table 9. Nutrients at Olympias and Skouries areas (bold values: values exceeding the EU limits).

\begin{tabular}{|c|c|c|c|c|c|c|}
\hline Date & Station & & $\mathrm{N}-\mathrm{NO}_{3} \mathrm{mg} \mathrm{l}^{-1}$ & $\mathrm{~N}-\mathrm{NO}_{2} \mathrm{mg} \mathrm{l}^{-1}$ & $\mathrm{~N}-\mathrm{NH}_{4} \mathrm{mg} \mathrm{l}^{-1}$ & $\mathrm{P}_{-} \mathrm{PO}_{4} \mathrm{mg} \mathrm{l}^{-1}$ \\
\hline \multirow{2}{*}{\multicolumn{3}{|c|}{$\begin{array}{l}\text { EU permitted value } \\
\text { EU suggested value }\end{array}$}} & 50 & 0.1 & 0.50 & - \\
\hline & & & 25 & - & 0.05 & - \\
\hline \multirow[t]{2}{*}{ November } & Olympias & Max. & $0.35(\mathrm{OL} 4)$ & 0.007 (OL1) & $0.002(\mathrm{OL} 1)$ & $0.517(\mathrm{OL} 4)$ \\
\hline & & Min. & $0.29(\mathrm{OL} 1)$ & $0.006(\mathrm{OL} 4)$ & $0.001(\mathrm{OL} 4)$ & $0.002(\mathrm{OL} 1)$ \\
\hline \multicolumn{7}{|c|}{ Sites exceeding the EU limits } \\
\hline & Skouries & Max. & 0.59 (SK1) & $0.001(\mathrm{SK} 4)$ & $0.003(\mathrm{SK} 4)$ & $0.085(\mathrm{SK} 1)$ \\
\hline & & Min. & 0.47 (SK4) & $0.000(\mathrm{SK} 1)$ & $0.002(\mathrm{SK} 1)$ & $0.082(\mathrm{SK} 4)$ \\
\hline \multicolumn{7}{|c|}{ Sites exceeding the EU limits } \\
\hline \multirow[t]{2}{*}{ January } & Olympias & Max. & $0.44(\mathrm{OL} 4)$ & 0.003 (OL4) & $0.073($ OL4) & $0.051(\mathrm{OL} 1)$ \\
\hline & & Min. & $0.31(\mathrm{OL} 1)$ & $0.002(\mathrm{OL} 1)$ & $0.011(\mathrm{OL} 1)$ & $0.045(\mathrm{OL} 4)$ \\
\hline \multicolumn{3}{|c|}{ Sites exceeding the EU limits } & & & OL4 & \\
\hline & Skouries & Max. & $0.36(\mathrm{SK} 4)$ & $0.002(\mathrm{SK} 1)$ & $0.010(\mathrm{SK} 1)$ & $0.059(\mathrm{SK} 1)$ \\
\hline & & Min. & $0.21(\mathrm{SK} 1)$ & $0.002(\mathrm{SK} 4)$ & $0.001(\mathrm{SK} 4)$ & $0.055(\mathrm{SK} 4)$ \\
\hline \multicolumn{7}{|c|}{ Sites exceeding the EU limits } \\
\hline \multirow[t]{2}{*}{ March } & Olympias & Max. & $0.41(\mathrm{OL} 1)$ & $0.003(\mathrm{OL} 1)$ & $0.002(\mathrm{OL} 1)$ & $0.095(\mathrm{OL} 1)$ \\
\hline & & Min. & $0.25(\mathrm{OL} 4)$ & 0.003 (OL4) & 0.002 (OL4) & $0.048(\mathrm{OL} 4)$ \\
\hline \multicolumn{7}{|c|}{ Sites exceeding the EU limits } \\
\hline & Skouries & Max. & $0.32(\mathrm{SK} 1)$ & $0.004(\mathrm{SK} 1)$ & $0.008(\mathrm{SK} 1)$ & $0.109(\mathrm{SK} 1)$ \\
\hline & & Min. & 0.03 (SK4) & $0.004(\mathrm{SK} 4)$ & $0.002(\mathrm{SK} 4)$ & $0.079(\mathrm{SK} 4)$ \\
\hline \multicolumn{7}{|c|}{ Sites exceeding the EU limits } \\
\hline \multirow[t]{2}{*}{ June } & Olympias & Max. & $0.31(\mathrm{OL} 4)$ & $0.004(\mathrm{OL} 1)$ & $0.017(\mathrm{OL} 1)$ & 0.198 (OL4) \\
\hline & & Min. & $0.25(\mathrm{OL} 1)$ & 0.003 (OL4) & $0.016(\mathrm{OL} 4)$ & $0.164(\mathrm{OL} 1)$ \\
\hline \multicolumn{7}{|c|}{ Sites exceeding the EU limits } \\
\hline & Skouries & Max. & $0.30(\mathrm{SK} 4)$ & $0.004(\mathrm{SK} 1)$ & $0.016(\mathrm{SK} 1)$ & $0.212(\mathrm{SK} 4)$ \\
\hline & & Min & $0.21(\mathrm{SK} 1)$ & $0.004(\mathrm{SK} 4)$ & $0.013(\mathrm{SK} 4)$ & $0.132(\mathrm{SK} 1)$ \\
\hline \multicolumn{7}{|c|}{ Sites exceeding the EU limits } \\
\hline \multirow[t]{2}{*}{ August } & Olympias & Max. & $0.59(\mathrm{OL} 4)$ & $0.000(\mathrm{OL} 1)$ & $0.090(\mathrm{OL} 4)$ & $0.200(\mathrm{OL} 4)$ \\
\hline & & Min. & $0.50(\mathrm{OL} 1)$ & 0.000 (OL4) & 0.057 (OL1) & $0.100(\mathrm{OL} 1)$ \\
\hline \multicolumn{3}{|c|}{ Sites exceeding the EU limits } & & & OL1 and OL4 & \\
\hline & Skouries & Max. & $0.88(\mathrm{SK} 4)$ & $0.000(\mathrm{SK} 1)$ & $0.054(\mathrm{SK} 1)$ & $0.100(\mathrm{SK} 1)$ \\
\hline & & Min. & 0.33 (SK1) & $0.000(\mathrm{SK} 4)$ & $0.054(\mathrm{SK} 4)$ & $0.100(\mathrm{SK} 4)$ \\
\hline \multicolumn{3}{|c|}{ Sites exceeding the EU limits } & & & SK1 and SK4 & \\
\hline
\end{tabular}

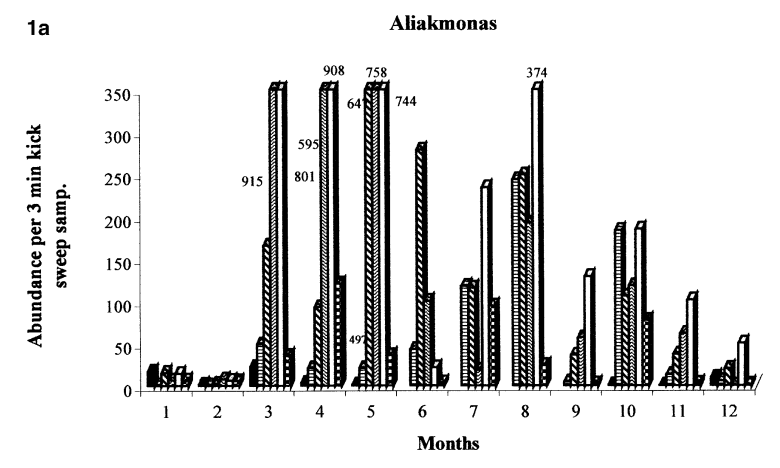

- Plecoptera 目Trichoptera \$Ephemeroptera 囷Oligochaeta $\square$ Chironomidae \$Diptera

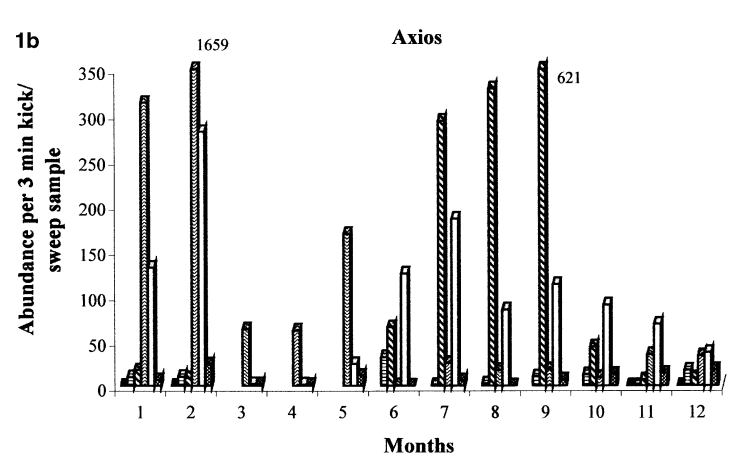

Dlecoptera 日Trichoptera \$Ephemeroptera 圈Oligochaeta $\square$ Chironomidae 娄 Diptera

Fig. 1. Monthly fluctuations of the abundance of the benthic macroinvertebrate groups in two sites in Aliakmon (a) and Axios (b) river. 
Table 10. Percentages of the taxa at Aliakmon River (Grevena + Niseli) (A), Axios river (B), Olympias area (C), Skouries area (D). Other taxa may be Odonata, Coleoptera, Hemiptera, Hirudinea, Amphipoda, Isopoda or/and Crustacea. (A: number of families, B: number of genera, C: dominant taxa).

A: Aliakmon river (Grevena + Niseli).

\begin{tabular}{|c|c|c|c|c|c|c|}
\hline \multirow[t]{2}{*}{ Main groups } & \multicolumn{2}{|c|}{ January } & \multicolumn{4}{|c|}{ March } \\
\hline & A & B & $\mathrm{C}$ & A & B & $\mathrm{C}$ \\
\hline Ephemeroptera & 6 & 6 & $\begin{array}{l}\text { Potamanthus sp. } 8.5 \% \\
\text { Baetis sp. } 2.85 \% \\
\text { Ecdyonurus sp. } 2.13 \%\end{array}$ & 7 & 9 & Baetis sp. $4.88 \%$ \\
\hline Plecoptera & 2 & 3 & $\begin{array}{l}\text { Rhabdiopteryx sp. } 13.52 \% \\
\text { Taeniopteryx sp. } 3.91 \%\end{array}$ & 2 & 3 & Rhabdiopteryx sp. $0.96 \%$. \\
\hline Trichoptera & 1 & 1 & Hydroptila sp. $1.09 \%$ & 4 & 5 & Hydropsyche sp. $1.53 \%$ \\
\hline Diptera & 7 & & $\begin{array}{l}\text { Rhagionidae } 1.78 \% \\
\text { Dolichopodidae } 1.78 \%\end{array}$ & 8 & & $\begin{array}{l}\text { Simuliidae } 0.83 \% \\
\text { Ceratopogonidae } 0.71 \%\end{array}$ \\
\hline Chironomidae & & & $14.95 \%$ & & & $40 \%$ \\
\hline Oligochaeta & & & $7.1 \%$ & & & $45.07 \%$ \\
\hline $\begin{array}{l}\text { Gastropoda (Pulmonata) } \\
\text { Gastropoda } \\
\text { (Prosobranchia) }\end{array}$ & 1 & 1 & Lymnaea sp. $7.83 \%$ & 1 & 1 & Physa sp. $0.33 \%$ \\
\hline \multirow{4}{*}{$\begin{array}{l}\text { Other taxa } \\
\text { Total }\end{array}$} & 5 & 5 & Elminthidae $24.55 \%$ & 5 & 5 & Coenagriidae $0.067 \%$ \\
\hline & 22 & & & 27 & & \\
\hline & \multicolumn{2}{|c|}{ June } & & \multicolumn{2}{|c|}{ August } & \\
\hline & A & B & $\mathrm{C}$ & A & $\mathrm{B}$ & $\mathrm{C}$ \\
\hline Ephemeroptera & 5 & 7 & $\begin{array}{l}\text { Baetis sp. } 43.9 \% \\
\text { Ephemerella sp. } 6.08 \% \\
\text { Ecdyonurus sp. } 4.21 \%\end{array}$ & 7 & 10 & $\begin{array}{l}\text { Ecdyonurus sp. } 8.92 \% \\
\text { Baetis sp } 5.46 \% \\
\text { Caenis sp } 3.64 \%\end{array}$ \\
\hline Plecoptera & & & & 2 & 2 & Leuctra sp. $0.34 \%$ \\
\hline Trichoptera & 7 & 8 & Psychomyia sp $6.9 \%$. & 4 & 5 & $\begin{array}{l}\text { Cheum/psyche sp } 13.05 \% \\
\text { Hydropsyche sp. } 3.03 \% \\
\text { Psychomyia sp. } 3.11 \% \text {. }\end{array}$ \\
\hline Diptera & 3 & & $\begin{array}{l}\text { Tipulidae } 0.41 \% \\
\text { Simuliidae } 0.28 \%\end{array}$ & 5 & & $\begin{array}{l}\text { Tabanidae } 0.71 \% \\
\text { Athericidae } 0.76 \%\end{array}$ \\
\hline Chironomidae & & & $4.35 \%$ & & & $29.59 \%$ \\
\hline Oligochaeta & & & $20.73 \%$ & & & $15.19 \%$ \\
\hline $\begin{array}{l}\text { Gastropoda (Pulmonata) } \\
\text { Gastropoda } \\
\text { (Prosobranchia) }\end{array}$ & 1 & 1 & Physa sp. $4.59 \%$ & 1 & 1 & Physa sp. $0.029 \%$ \\
\hline Other taxa & 4 & 5 & $\begin{array}{l}\text { Haliplidae } 3.25 \% \\
\text { Corixidae } 1.52 \%\end{array}$ & 4 & 5 & Elminthidae $13.4 \%$ \\
\hline Total & 20 & & & 23 & & \\
\hline
\end{tabular}

\begin{tabular}{|c|c|c|c|}
\hline & \multicolumn{3}{|c|}{ November } \\
\hline Ephemeroptera & 5 & 5 & Caenis sp. $2.71 \%$ Potamanthus sp. $6.22 \%$ \\
\hline Plecoptera & 2 & 2 & Taeniopteryx sp. $0.87 \%$ Leuctra sp. $0.87 \%$ \\
\hline Trichoptera & 4 & 4 & Psychomyia sp. $2.1 \%$ \\
\hline Diptera & 3 & & Ceratopogonidae $0.26 \%$ Tabanidae $0.26 \%$ Tipulidae $0.087 \%$ \\
\hline Chironomidae & & & $26.62 \%$ \\
\hline Oligochaeta & & & $16.11 \%$ \\
\hline \multicolumn{4}{|c|}{ Gastropoda (Pulmonata) } \\
\hline \multicolumn{4}{|c|}{ Gastropoda } \\
\hline \multicolumn{4}{|l|}{ (Prosobranchia) } \\
\hline Other taxa & 5 & 5 & Asellus sp. $41.33 \%$ \\
\hline Total & 19 & & \\
\hline
\end{tabular}


Table 10. Continued.

B: Axios river (Evzoni site + Anatoliko site).

\begin{tabular}{|c|c|c|c|c|c|c|}
\hline \multirow[t]{2}{*}{ Main groups } & \multicolumn{2}{|c|}{ January } & \multicolumn{4}{|c|}{ March } \\
\hline & A & $\mathrm{B}$ & $\mathrm{C}$ & A & $\mathrm{B}$ & $\mathrm{C}$ \\
\hline Ephemeroptera & 3 & 3 & Caenis sp. $3.35 \%$ & & & \\
\hline Plecoptera & 1 & 1 & Rhabdiopteryx sp. $0.03 \%$ & & & \\
\hline Trichoptera & 2 & 2 & Hydropsyche sp. $1.71 \%$ & & & \\
\hline Diptera & 6 & & Simuliidae $0.91 \%$ & 1 & & Dolichopodidae $0.4 \%$ \\
\hline Chironomidae & & & $26.38 \%$ & & & $2.03 \%$ \\
\hline Oligochaeta & & & $63.04 \%$ & & & $74.8 \%$ \\
\hline Gastropoda (Pulmonata) & 1 & 1 & Physa sp. $0.87 \%$ & 2 & 2 & Physa sp. $2.44 \%$ \\
\hline $\begin{array}{l}\text { Gastropoda } \\
\text { (Prosobranchia) }\end{array}$ & 1 & 1 & Hydrobiidae $0.07 \%$ & 1 & 1 & Hydrobiidae $15.45 \%$ \\
\hline Other taxa & 3 & 3 & Gammarus sp. $3.42 \%$ & 1 & 1 & Gammarus sp. $4.06 \%$ \\
\hline \multirow[t]{3}{*}{ Total } & 17 & & & 5 & & \\
\hline & \multicolumn{2}{|c|}{ June } & & \multicolumn{3}{|c|}{ August } \\
\hline & A & $\mathrm{B}$ & $\mathrm{C}$ & A & $\mathrm{B}$ & $\mathrm{C}$ \\
\hline $\begin{array}{l}\text { Ephemeroptera } \\
\text { Plecoptera }\end{array}$ & 4 & 5 & Canis sp. $24.26 \%$ & 3 & 5 & Caenis sp. $68.86 \%$ \\
\hline Trichoptera & 1 & 1 & Hydropsyche sp. $14.11 \%$ & 2 & 2 & Hydroptila sp. $0.37 \%$ \\
\hline Diptera & & & & 1 & & Scatopsidae $0.07 \%$ \\
\hline Chironomidae & & & $54.70 \%$ & & & $18.89 \%$ \\
\hline Oligochaeta & & & $0.3 \%$ & & & $3.88 \%$ \\
\hline Gastropoda (Pulmonata) & & & - & 1 & 1 & Physa sp. $0.15 \%$ \\
\hline $\begin{array}{l}\text { Gastropoda } \\
\text { (Prosobranchia) }\end{array}$ & & & - & & & \\
\hline Other taxa & 3 & 3 & $\begin{array}{l}\text { Gomphidae } 0.59 \% \\
\text { Mysidacea } 0.59 \%\end{array}$ & 3 & 4 & Gomphidae $0.15 \%$ \\
\hline Total & 8 & & & 10 & & \\
\hline
\end{tabular}

\begin{tabular}{|c|c|c|c|}
\hline & & ven & \\
\hline & A & $\mathrm{B}$ & $\mathrm{C}$ \\
\hline Ephemeroptera & 2 & 2 & Caenis sp. $19.11 \%$ \\
\hline Plecoptera & & & \\
\hline Trichoptera & 2 & 2 & Hydropsyche sp $20.94 \%$. \\
\hline Diptera & 3 & & Tipulidae $3.67 \%$ \\
\hline Chironomidae & & & $31.34 \%$ \\
\hline Oligochaeta & & & $15.9 \%$ \\
\hline Gastropoda (Pulmonata) & 1 & 1 & Physa sp. $0.15 \%$ \\
\hline $\begin{array}{l}\text { Gastropoda } \\
\text { (Prosobranchia) }\end{array}$ & & & \\
\hline Other taxa & 3 & 3 & Gomphidae $0.46 \%$ \\
\hline Total & 11 & & \\
\hline
\end{tabular}




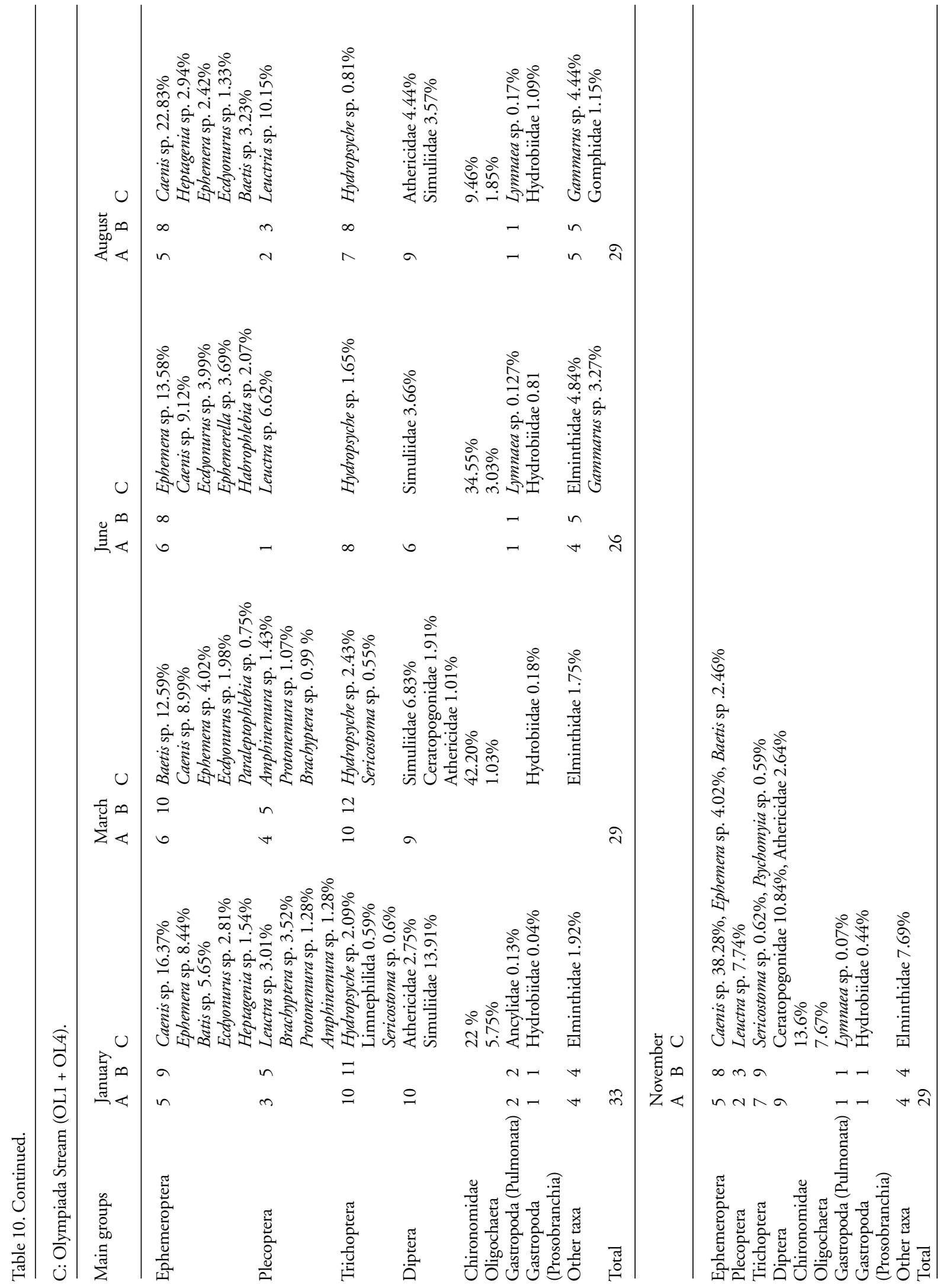




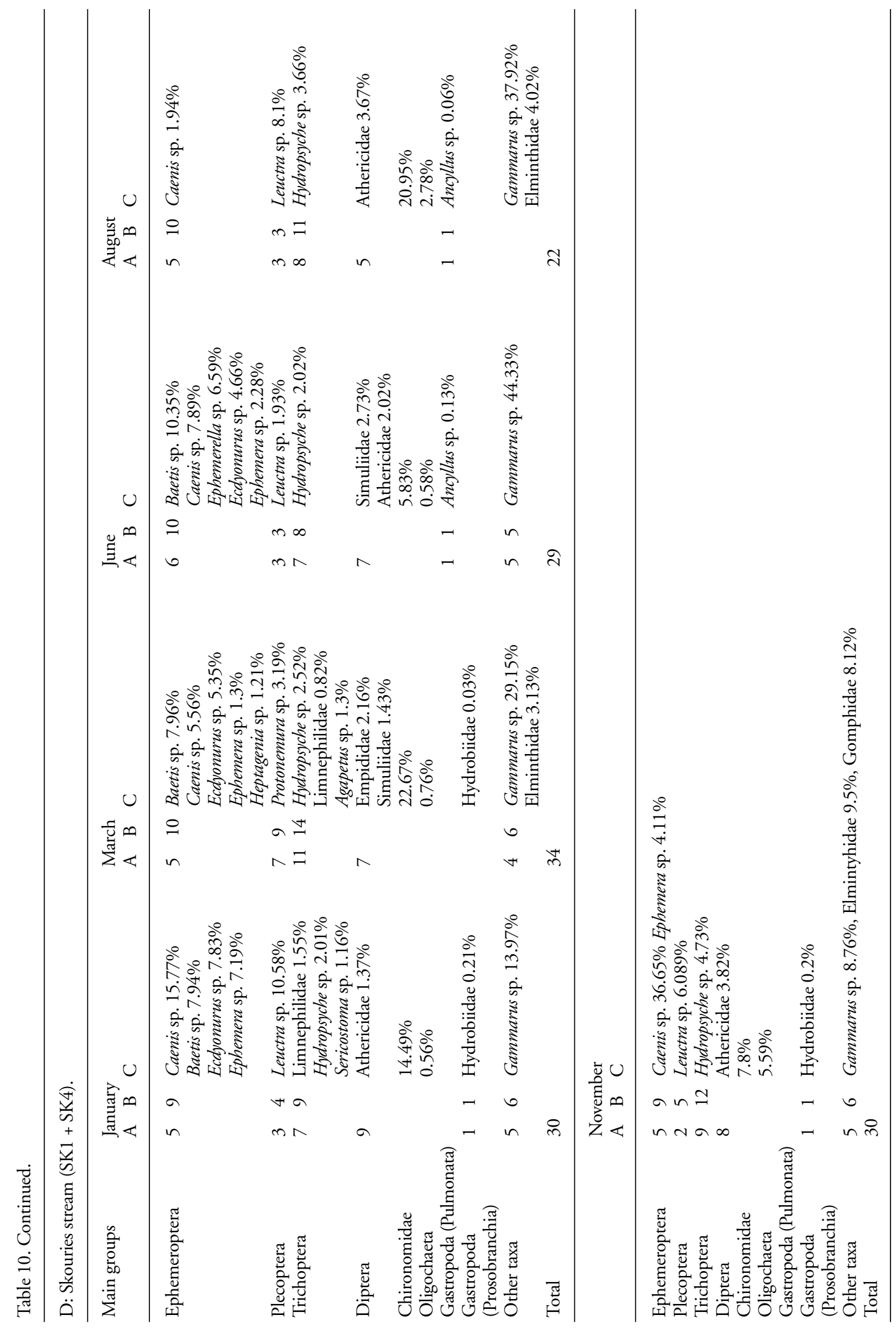


the small rivers, streams or creeks is free of distinct seasonality in phenology for $50 \%$ of dominant benthic macroinvertebrate groups. In the plain parts of large rivers, however, seasonality characterizes all the groups as happens with other animal groups in the Mediterranean region (Argyropoulou et al. 1993, 1994, Stamou et al. 1993). Accordingly, in Axios Ephemeroptera and Chironomidae peak at the same time (June-November) whereas Oligochaeta, that occupy almost the same habitat with Chironomidae, peak from November to June when water quality is poor mainly due to TSS.

\section{References}

Anagnostopoulou, M. 1992. The relationship between the macroinvertebrate community and water quality, and the applicability of biotic indices in the River Almopeos system (Greece). - M.Sc . thesis, Dept Environmental Biology, Univ. Manchester, Manchester, U.K.

Anagnostopoulou, M., Lazaridou-Dimitriadou, M. and White, K. N. 1994. The freshwater invertebrate community of the system of the river Almopeos, N. Greece. - Proc. 6th Int. Congr. on the Zoogeography and Ecology of Greece and the Adjacent Regions. Bios (Macedonia, Greece) 2: 79-86.

Argyropoulou, M. D. et al. 1993. Colonization patterns of decomposing litter in a maquis ecosystem. - Eur. J. Soil Biol. 29: 183-191.

Argyropoulou, M. D., Stamou, G. P. and Iatrou, G. D. 1994. Temporal and spatial distribution patterns of Collembola in a patchy environment. - Eur. J. Soil Biol. 30(2): 63-69.

Artemiadou, V., Kampa, E. and Lazaridou-Dimitriadou, M. 1999. Estimation of the ecological quality of surface waters of the river Axios (central Macedonia) during 1997. - Proc. VIII European Ecol. Congr. "The European dimension in Ecology; perspectives and challenges for the 21st century", Halkidiki, Greece, pp. 407.

Bobori, D. and Mourelatos, S. 1999. Psysicochemical parameters and nutrients content of surface waters of the Aliakmon river (Greece). - Freshenius Environ. Bull. 8: 718-723.

Cajaraville, M. P. et al. 1995. Cellular biomarkers as useful tools in the biological monitoring of environmental pollution: molluscan diagestive lysosomes. - In: Cajaraville, M. P. (ed.), Cell biology in environmental toxicology. Univ. Basque Country Press Service, Bilbao, pp. 29-55.

Castella, E. et al. 1995. The effects of water abstractions on invertebrate communities in U.K. streams. - Hydrobiologia 308: 167-182.

Chesters, R. K. 1980. Biological monitoring working party. The 1978 national testing exercise. - Depat of Environment, Water Data Unit, Technical memorandum 19: 1-37.

Commission of the European Communities COM 1998. 76 final. Amended proposal for a council directive establishing a framework for community action in the field of water policy (COM (1997) 49 final). - Presented by the Commission pursuant to Article $189 \mathrm{a}(2)$ of the EC Treaty.

Copeland, R. S. et al. 1997. Ecological quality of the water in the catchment of river Aliakmonas (Macedonia, Greece). - Proc. 5th Int. Congr. of Environmental Science and Technology, Molyvos, Greece, 2, pp. 27-36.

De Pauw, N. and Vanhooren, G. 1983. Methods for biological assessment for water courses in Belgium. - Hydrobiologia 100: 153-168.

Drouin, S. et al. 1999. An integrated water quality assessment of the river Axios during the 1998 low flow season. - Proc. 6th Int. Congr. of Environmental Science and Technology, Samos, Greece, 1, pp. 120-129.

Equihua, M. 1990. FUZZY clustering of ecological data. - J. Ecol. 78: 519-534.

Ford, J. et al. 1998. Ecological evaluation of water quality in river Mavrolakkas (Olympiada, Halkidiki) from May to August 1998. - Proc. Int. Conf. "Protection and Restoration of the Environment IV”, Chalkidiki, Greece, 1, pp. 144-152.

Graca, M. A. S., Fonseca, D. M. and Castro, S. T. 1989. The distribution of macroinvertebrates communities in two Portuguese rivers. - Freshwat. Biol. 22: 297-308.

Hellawell, J. M. 1986. Biological indicators of freshwater pollution and environmental management. - Elsevier.

Hynes, H. B. N. 1970. The ecology of running waters. - Liverpool Univ. Press.

Jennings, J. R. et al. 1999. A preliminary investigation into the ordination and classification of Greek rivers. - Proc. 6th Int. Congr. of Environmental Science and Technology, Samos, Greece, 1, pp. 103-111.

Klecka, W. R. 1975. Discriminant analysis. SPSS statistical package for social sciences. - In: Nie, N. H. et al. (eds), McGrawHill, pp. 434-67.

Kouimtzis, T. et al. 1994. Evaluation of the chemical parameters in Aliakmon river, N. Greece. Part I: quality characteristics and nutrients. - J. Environ. Sci. Health A29: 2115-2126.

Langrick, J. et al. 1998. An integrated water quality assessment of the river Axios, northern Greece. - Proc. Int. Conf. "Protection and Restoration of the Environment IV", Chalkidiki, Greece, 1, pp. 136-143.

Lazaridou-Dimitriadou, M. et al. 2000. Contribution to the ecological quality of Aliakmon river (Macedonia, Greece): a multivariate approach. - Proc. Int. Congr. "Man and River Systems. The functioning of River Systems at the Basin scale", Hydrobiologia 410: 47-58.

Marchant, R., Barmutta, L. A. and Chessman, B. C. 1994. Preliminary study of the ordination and classification of macroinvertebrate communities from running waters in Victoria, Australia. - Aust. J. Mar. Freshwater Res. 45: 945-962.

Mason, C. F. 1991. Biology of freshwater pollution. - Longman Scientific and Technical, 2nd ed.

Metcalfe, J. L. 1989. Biological water quality assessment of running waters based on macroinvertebrate communities: history and present status in Europe. - Environ. Pollut. 60: 101139.

Stamou, G. P. et al. 1993. Ecological time versus standard clock time: the asymmetry of phenologies and the life history strategies of some soil arthropods from Mediterranean ecosystems. - Oikos 66: 27-35.

Vukmirovic, M. et al. 1994. DNA damage in marine mussel Mytillus galloprovinciallis as a biomarker of environmental contamination. - Mar. Ecol. Prog. Ser. 109: 165-171.

Wright, J. F. 1995. Development and use of a system for predicting the macroinvertebrate fauna in flowing streams. - Aust. J. Ecol. 20: 181-197.

Yfantis, et al. 1999. Ecological evaluation of water quality in the river Aliakmonas (Macedonia, Hellas). - Contrib. to Zoogeogr. and Ecol. of the Eastern Mediterranean Region 1: 485493. 